\title{
The Risk of Earth Destabilization (RED) index, aggregating the impact we make and what the planet can take
}

Yanne Goossens ${ }^{a}$, Johan De Tavernier ${ }^{b}$, Annemie Geeraerd ${ }^{a}{ }^{*}$

${ }^{a}$ KU Leuven, Faculty Bioscience Engineering, Department of Biosystems (Division MeBioS) and Ethics@Arenberg, W. de Croylaan 42 - box 2428, B-3001 Leuven, Belgium.

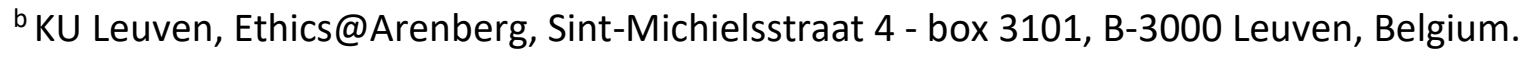

* Corresponding Author: annemie.geeraerd@kuleuven.be

Creative Commons Attribution Non-Commercial No Derivatives License

Accepted for publication in the Journal of Cleaner Production on June 28, 2018

Published in Journal of Cleaner Production Volume 198, 10 October 2018, Pages 601-611 


\section{Abstract}

The current golden standard for calculating the environmental impact of a product or process is the Life Cycle Assessment (LCA) approach, leading to results in a large number of impact categories, such as climate change, acidification and toxicity. In the absence of information on which impact category to prioritize, alike products cannot easily be compared and judging environmental sustainability remains difficult. To facilitate transparent communication about the sustainability of products and processes to all members in society, we present a novel environmental index: the Risk of Earth Destabilization (RED) index. Using weighting factors based on the Planetary Boundaries framework, the index takes into account the "planetary urgency", and hence the risk of earth destabilization associated with each of the LCA impacts. The methodology proposed further refines the work done by Tuomisto and co-workers (2012), thereby contributing to the ongoing efforts within the EU Environmental Product Footprint project for developing weighting factors and building single score indices. A case study on meat consumption options (beef, pork, poultry) illustrates the broad applicability of the RED index and visualization options.

\section{Graphical abstract}
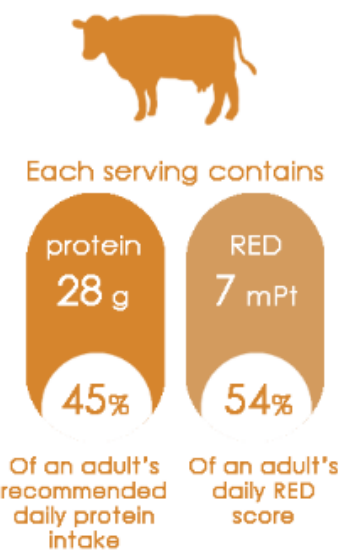
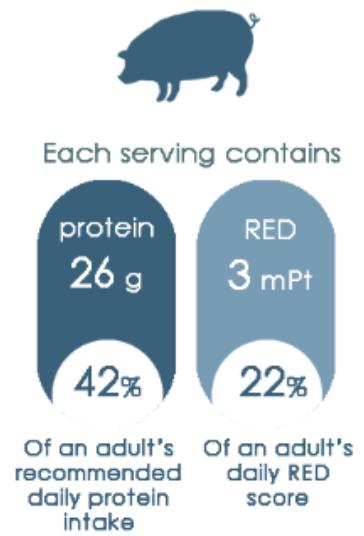
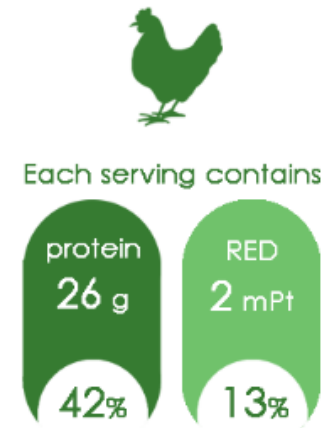

Of an adult's $\begin{gathered}\text { Of an adult's } \\ \text { daily RED } \\ \text { recommended } \\ \text { daily protein } \\ \text { intake }\end{gathered}$
score 
Keywords

environmental performance; life cycle assessment; planetary boundaries; weighting; single score index; sustainability

Highlights

- We present a novel environmental index: Risk of Earth Destabilization (RED) index

- Index facilitates interpretation of published life cycle assessment (LCA) results

- Planetary Boundaries-based weighting factors indicate "planetary urgency"

- A case study illustrates broad applicability of index and visualisation options 


\section{Introduction}

Citizens and policy makers are increasingly concerned with the environmental impacts associated with the goods we consume. Ecological burdens and human health impacts connected with the entire product life cycle can be calculated using the Life Cycle Assessment (LCA) approach (ISO, 2006a, 2006b). After compiling a life cycle inventory, inventory data are multiplied with characterization factors, resulting in impact indicator results. This can be done at either the midpoint level where the categories focus on a single environmental problem such as climate change, acidification or human toxicity, at the endpoint level where the impacts express damages done to areas of protection such as human health or natural resources, or through a combination of both whereby the inventory is first characterized into midpoint impacts and then subsequently characterized into endpoint impacts (Hauschild et al., 2013).

Interpretation of a collection of midpoint or endpoint impacts may not always be straightforward. As such, for communication purposes, LCA results can be converted into a single environmental index. Impacts are therefore first normalized to frame its relative magnitude by presenting them relative to reference impacts, such as the impact of one person living in Europe (Benini et al., 2014; Bjørn and Hauschild, 2015; Brentrup et al., 2004; Sleeswijk et al., 2008). Next, to take into account the potential harm to the environment, the dimensionless normalized impacts are multiplied with weighting factors, after which they are aggregated into a single index (Brentrup et al., 2004).

The last decades, several life cycle impact assessment methods (LCIA) have been proposed, each of them having its own set of midpoints and/or endpoint characterization factors, with many of them being complemented with normalization and weighting factors as described by the EU Joint Research Centre (EC-JRC, 2010) and Pré (2017). In 2013, the European Product Environmental Footprint (PEF) pilot phase was set up, aiming at providing consumers with harmonized information on the environmental performance of products. Within this project, the International Reference Life Cycle Data System (ILCD) is put forward as LCIA method to calculate the impacts associated with a specific product (category), leading to results expressed in 16 midpoint ICs, of which one is an interim category (EC-JRC, 2011; European Commission, 2013; Hauschild et al., 2013). The pilot phase further entailed testing of normalization and weighting factors for the midpoint impacts (European Commission, 2016a, 2016b). In the meantime, normalization factors have been determined (European Commission, 2016a) whereas weighting factors are currently being investigated (Benini et al., 2015). 
The present study contributes to this ongoing process by proposing weighting factors which convert LCA results, expressed in ILCD impact categories, into a new environmental index called "the Risk of Earth Destabilization (RED) index". The index and its associated weighting factors hereby comply with the following essential requirements. Firstly, the index should facilitate interpretation and evaluation of LCA midpoint impact results (LCA output) as found in current and future scientific LCA literature and databases. Details on the inventory phase are typically not available in existing LCA literature and therefore the index should only rely upon the LCA output. Secondly, the weighting factors used should be based on scientifically valid targets, building on recent developments on measuring risk of earth destabilization, namely the concept of Planetary Boundaries (PB).

The Planetary Boundaries (PB) framework defines a safe operating space for humanity with respect to the earth system through the identification of control variables and planetary boundaries for nine key earth system processes (Rockström et al., 2009a, 2009b; Steffen et al., 2015). For each control variable, a threshold or boundary is set which should not be passed in order to maintain a resilient earth system, combining both upper limits (maximum thresholds) and lower limits (minimum limits). Additionally, for each PB, a zone of uncertainty was identified which captures both gaps and weaknesses in the scientific knowledge base and intrinsic uncertainties in the functioning of the earth system. For four of the earth system processes (climate change, change in biosphere integrity, biogeochemical flows, and land-system change), the anthropogenic perturbation levels have already trespassed the proposed global boundary values (Rockström et al., 2009a, 2009b; Steffen et al., 2015).

Table 1 provides an overview of the planetary boundaries concept, listing the earth system processes, control variables, planetary boundaries, nature of limit (upper or lower limit) and zones of uncertainty based on Steffen et al. (2015). As indicated in the table, the current perturbation level of an earth system can be considered as "safe" according to Steffen and co-workers (2015) if the current value of a control value has not trespassed the proposed PB (marked with green). In case the PB is being trespassed but we are still within the zone of uncertainty, we find ourselves in a situation of "increased risk" of irreversibly driving the earth into a less hospitable state (marked with orange). Lastly, in case the current value of the control variable has also trespassed the zone of uncertainty of the proposed PB, we are in a situation of "high risk" (marked with red). 
In 2017, a study was published on the environmental impacts associated with food and beverages consumption in the EU, making use of an "EU Basket of Products (BoP) for food" (Notarnicola et al., 2017). This basket gathers products that are believed to be representative for food consumption for the year 2010 in Europe. Environmental impacts are calculated on a life-cycle basis, resulting in impacts expressed in a wide range of impact categories. As such, results can at this moment not easily be communicated to the general public. For illustrative purposes, we will therefore apply the RED approach to this study. Furthermore, the case study is used to present a potential visualization approach for the RED index, applicable within the context of food.

\section{Material and methods}

\subsection{Building the index}

\subsubsection{Linking the PB and LCA frameworks}

In the following subsections, we describe, as the first step for building our index, the scientific linkages between the nine earth system processes within the PB framework (as shown in Table 1) with the LCA ICs, and select a relevant set of LCA midpoint impact categories to represent the PB earth system processes and their respective control variables. Following the great stakeholder involvement in the PEF project mentioned in the introduction section, we can expect the methods proposed within the PEF pilot phase, such as the use of the ILCD impact assessment method (European Commission, 2013), to become the standard in Europe for measuring product environmental performance. For this reason, it was decided to use the ILCD framework as our LCA framework, even though it has so far only been used to a limited extent in academic literature.

It is important to note from the onset that the current set of linkages is open for improvement in the future, while keeping the concept of our research (the RED index). An overview of the current linkages can be found in the three left columns of Table 2; the last three columns result from calculations explained in Sections 2.1.2 and 2.1.3. 


\subsubsection{PB Earth system processes that could be linked to impact categories (IC) in the LCA framework}

PB Earth system process "Climate Change" \& LCA IC "Climate Change". The PB boundaries relate to atmospheric carbon dioxide $\left(\mathrm{CO}_{2}\right)$ concentration and to the energy imbalance of top of the atmosphere, caused by changes in radiative forcing (Rockström et al., 2009a; Steffen et al., 2015). This is strongly related to the climate change $\mathrm{IC}$, which takes into account $\mathrm{CO}_{2}$ and other greenhouse gases, based on their global warming potential and thus reflecting their radiative forcing ability (Goedkoop et al., 2013). As the PB control variable on radiative forcing is thought to be the more inclusive and fundamental (Steffen et al., 2015), the control variable "energy imbalance of top of the atmosphere" can be linked to the climate change IC.

PB Earth system process "Stratospheric ozone depletion"\& LCA IC "Ozone depletion". The boundary is based on the ozone concentration (Rockström et al., 2009a; Steffen et al., 2015) and can be linked to the ozone depletion IC. The other ozone related IC, namely photochemical ozone formation, refers to ground level or tropospheric ozone (summer smog) and is therefore not relevant for this PB.

PB Earth system process "Biogeochemical flows". The three boundaries currently focus on nitrogen (N) and phosphorous (P) inputs (Rockström et al., 2009a; Steffen et al., 2015).

(i) The PB control variable "global-level boundary for $\mathrm{P}$ " relates to phosphorous (P) flows from freshwater into the ocean. This boundary can be linked to the IC marine eutrophication.

(ii) The PB control variable "regional-level boundary for P" refers to phosphorous flows from fertilizers to erodible soils, which eventually result in phosphorous flows to freshwater. This boundary excludes phosphorous that is being recycled within the agricultural system, such as phosphorous from manure (Steffen et al., 2015). Even though the IC freshwater eutrophication does actually include impacts resulting from the application of manure, this category was - for now - considered the best available option for linking the LCA framework with the regional-level boundary for $P$.

(iii) The PB control variable "global-level boundary for N" refers to intentionally fixed reactive nitrogen $(\mathrm{N})$ in the agricultural system. This includes both industrial fixation related to the production of fertilizers through the Haber-Bosch process and to biological fixation of $\mathrm{N}$ such 
as planting of leguminous crops, while unintended $\mathrm{N}$ fixation resulting from combustion related nitrogen oxide emissions in transport and industry is excluded (de Vries et al., 2013; Steffen et al., 2015). Steffen and co-workers (2015) further decided to focus the nitrogen PB control variable on aquatic ecosystem eutrophication relating to the $\mathrm{N}$ flow from the soil to the freshwater system (such as nitrogen leaching and run-off to ground and surface waters), since all emissions to air stemming from intentionally fixed $\mathrm{N}$ (such as ammonia and nitrous oxide emissions) are already addressed in the climate change boundary on radiative forcing. As such, again, a link can be made with the IC freshwater eutrophication.

A small yet important technical detail for the control variables in (i) and (iii) is the following. The ICs on marine and freshwater eutrophication (as well as their associated normalization factors (NF)) are expressed in respectively $\mathrm{kg} \mathrm{N}$ and $\mathrm{kg} P$ equivalents as $\mathrm{N}$ and $\mathrm{P}$ are assumed to be the limiting nutrient in respectively marine and freshwater ecosystems in Europe (Goedkoop et al., 2013). The IC marine eutrophication is linked to the PB control variable "P global". As such, it would be appropriate to convert the LCA result for marine eutrophication (and the associated NF), expressed in $\mathrm{kg} \mathrm{N}$ equivalents, into $\mathrm{kg} P$ equivalents. A proper conversion factor is the Redfield ratio, which says that the atomic ratio for N:P in phytoplankton equals 16:1 (Redfield et al., 1963). Similarly, the IC freshwater eutrophication (and its NF) is expressed in kg P equivalents whereas its associated PB control variable refers to "N global". In this case, the N:P ratio in growing plant tissue of agricultural crops, which is on average 11.8 (Steffen et al., 2015), could be used as conversion factor. The final RED index, as developed further in this paper, involves the ratio of the LCA impact results by their NFs (see Equation 6). As such, the conversion factors for the LCA results and the associated NFs are lost in the division. No conversion is therefore needed here and the LCA results can be used in their current form.

PB Earth system process "Land-system change" \& LCA IC "Land use". The boundary refers to the amount of forest cover remaining, following the great role the tropical, temperate and boreal forests play in land surface-climate coupling (Steffen et al., 2015). The IC land use, expressed in kg carbon deficit, refers to the mass of carbon lost from the soil during land transformation and occupation (Brandão et al., 2011; Milà i Canals et al., 2007). Although changes of soil organic matter may also occur in the absence of forest cover loss, this impact category was considered to be the best available candidate for representing the PB land-system change. 
PB Earth system process "Freshwater use" and LCA IC "Water resource depletion". Fresh water use sets limits on global-level consumptive use of blue water from rivers, lakes, reservoirs and renewable groundwater stores and on basin-scale blue water withdrawal (Rockström et al., 2009a; Steffen et al., 2015). These are linked to the IC water resource depletion which refers to the volume of freshwater used while also taking into account the local scarcity of water (Frischknecht et al., 2009).

\subsubsection{PB Earth system processes that could not (yet) be linked to impact categories (IC) in the LCA framework}

PB Earth system process "Change in biosphere integrity". Boundaries are set for both genetic diversity and functional biodiversity (Rockström et al., 2009a; Steffen et al., 2015). These are both considered to be interim control variables for which great uncertainty surrounds the set boundaries. No relevant midpoint ICs could be found within the ILCD impact assessment method, as the PB on biosphere integrity can be considered as an endpoint indicator rather than a midpoint indicator. A better understanding of the cause-effect relationship between biosphere and all contributing impacts is required in order to link this PB to the LCA framework in the future (Ryberg et al., 2016).

PB Earth system process "Ocean acidification". The boundary refers to the aragonite saturation state of the surface ocean (Rockström et al., 2009a; Steffen et al., 2015): increased acidification leads to decreased aragonite saturation, potentially resulting in large-scale depletion of aragonite-forming organisms and subsequent major disturbances in marine ecosystems (Rockström et al., 2009a). Ocean acidification is mainly influenced by absorption of atmospheric $\mathrm{CO}_{2}$ and is thus linked to the IC climate change, expressed in $\mathrm{CO}_{2}$ eq. Nevertheless, this impact category also includes other greenhouse gases besides $\mathrm{CO}_{2}$ which are not necessarily linked to ocean acidification. Additionally, adherence to the climate change PB already implies adherence to the ocean acidification PB (Steffen et al., 2015); it was therefore deemed unnecessary to also link the ocean acidification PB to the IC climate change. Ocean acidification may further be influenced by non- $\mathrm{CO}_{2}$ acidification sources from atmospheric nitrogen and sulphur deposition, in particular in coastal waters, and the PB could thus in principle also be linked to the LCA acidification impact category. However, because of the many uncertainties surrounding the magnitude of this non- $\mathrm{CO}_{2}$ acidification (Doney et al., 2007), it was decided not to consider this link. 
PB Earth system process "Atmospheric aerosol loading". The boundaries are based on the effect of aerosols on regional ocean-atmosphere circulation (Rockström et al., 2009a; Steffen et al., 2015). Aerosol impacts are to a certain extent covered by the IC climate change, but with no consideration of regional specificities; a more appropriate linkage is the IC particulate matter. However, in the absence of a regional boundary for Europe, the two frameworks could - for now - not be linked.

PB Earth system process "Introduction of novel entities". The boundary considers new substances, new forms of existing substances, and modified life forms that have the potential for unwanted geophysical and/or biological effect (Rockström et al., 2009a; Steffen et al., 2015). This could refer to the ICs on human health, ecotoxicity and potentially even ionizing radiation. However, as no control variable has been defined so far, it is not possible to link this boundary with any of the LCA ICs.

\subsubsection{Development of PB-based weighting factors}

To take into account the "planetary urgency" associated with each of the LCA impacts, both the boundaries and the zones of uncertainty set for each PB control variable need to be considered. Weighting factors (WFs) often follow a distance-to-target approach, whereby the distance between the current level of an environmental impact to the target value determines the weighting of each impact category (Huppes and Oers, 2011; Tuomisto et al., 2012). This approach was followed to calculate novel planetary boundarybased WFs for each control variable $i$ which indicate the status of each control variable: not surpassed the PB (situation "no risk/safe", marked with green in Table 1), surpassed the PB but within zone of uncertainty of the proposed PB ("increasing risk", marked with orange), or surpassed both the PB and its zone of uncertainty ("high risk", marked with red). The approach taken is outlined here below; a resulting overview is given in Table 2. This paper hereby builds on previous work done in this field, further refining the methodology suggested by Tuomisto and co-workers (2012) as will be described in the discussion section.

Step 1: the Boundary Weighting Factor $\left(\mathrm{WF}_{\text {Boundary, } i}\right)$, indicates whether the boundary value has been trespassed. 
In case the boundary relates to a maximum value not to be exceeded ("upper" limit in Table 1), the current value of the control variable is divided by this upper boundary value (Equation 1). An example is the PB control variable "energy imbalance of top of atmosphere": division of the current value of the control variable $\left(2.3 \mathrm{~W} / \mathrm{m}^{2}\right.$, Table 1$)$ by its boundary value (set at $\left.1.0 \mathrm{~W} / \mathrm{m}^{2}\right)$, results in a $W F_{\text {Boundary }}$ of 2.3 .

$$
\mathrm{WF}_{\mathrm{Boundary}-\text { upper }, i}=\frac{\text { current value of control variable } i}{\text { PB for control variable } i}
$$

In case of a boundary representing a minimum value to be achieved ("lower" limit in Table 1), the ratio in Equation 1 is reversed: now, the boundary is divided by the current value of the control variable (Equation 2). For example for the PB control variable "stratospheric ozone concentration", the boundary value (275.5 DU) is divided by the current value (283 DU), leading to $\mathrm{WF}_{\text {Boundary }}$ of 0.97 .

$$
\mathrm{WF}_{\text {Boundary-lower, } i}=\frac{\mathrm{PB} \text { for control variable } i}{\text { current value of control variable } i}
$$

If the boundary has not been trespassed, we are in the safe operating space ("no risk/safe", marked with

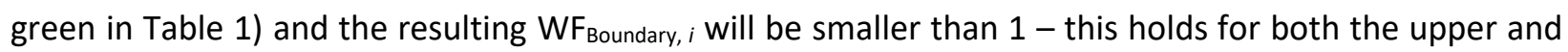
the lower versions. If the safe boundary is crossed, the $W F_{\text {Boundary, } i}$ will be above 1 . The $W_{F_{B o u n d a r y} i}$ thus indicates a sense of urgency: the higher the $\mathrm{WF}_{\text {Boundary, } i}$ for an earth system change, the higher the human perturbation beyond the safe boundary.

Step 2: the Uncertainty Weighting Factor (WF Uncertainty,i) indicates whether or not we are within the zone of uncertainty.

If the current value of the control variable is still within the zone of uncertainty (situation "no risk/safe" or "increasing risk", respectively marked with green or orange in Table 1), this weighting factor equals 1. An example is the PB control variable "stratospheric ozone concentration".

In case of crossing both the PB as well as the upper or lower boundary of the zone of uncertainty of the PB (for respectively upper or lower limits), we find ourselves in a zone of "high risk", as marked in red in Table 1. In that case, the WF is calculated by dividing the current value of the control variable by the upper limit of the proposed uncertainty zone in case of upper boundaries (Eq. 3); for lower boundaries, the reverse ratio is applied (Eq. 4). In the example of the PB control variable "energy imbalance of top of 
atmosphere", division of the current value $2.3 \mathrm{~W} / \mathrm{m}^{2}$ by the (upper) limit value of its zone of uncertainty $\left(1.5 \mathrm{~W} / \mathrm{m}^{2}\right)$ results in a WFuncertainty of 1.5 .

$$
\begin{aligned}
& \mathrm{WF}_{\text {Uncertainty-upper, } i}=\frac{\text { current value of control variable } i}{\text { upper boundary of uncertainty zone of the PB }} \\
& \mathrm{WF}_{\text {Uncertainty-lower, } i}=\frac{\text { lower boundary of uncertainty zone of the PB }}{\text { current value of control variable } i}
\end{aligned}
$$

Step 3: the Risk of Earth Destabilization Weighting Factor $\left(\mathrm{WF}_{\mathrm{RED}, i}\right)$ is obtained by multiplying the WFs from above, as shown in Equation 5, and this for both the lower and upper limits. The multiplication aims to magnify the weighting for impact categories that are surpassed, even when taking into account actual uncertainties surrounding the planetary boundaries.

$$
\mathrm{WF}_{\mathrm{RED}, i}=\mathrm{WF}_{\text {Boundary, } i} * \mathrm{WF}_{\text {Uncertainty }, i}
$$

\subsubsection{Aggregation into the "Risk of Earth Destabilization (RED) index"}

Next, using LCA output results, the "Risk of Earth Destabilization (RED) index" is calculated based on Equation 6.

$$
\mathrm{RED}=\sum_{i} \mathrm{RED}_{i}=\sum_{i} \frac{\operatorname{Impact}_{\mathrm{LCA}, i} * \mathrm{WF}_{\mathrm{RED}, i}}{\mathrm{~N}_{i}}
$$

where RED is the resulting aggregated Risk of Earth Destabilization score (expressed in RED points), RED $i$

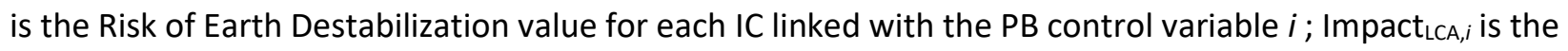
LCA midpoint impact for each IC linked with the PB control variable $i$; $W_{\mathrm{RED}, i}$ is the PB-based Risk of Earth Destabilization Weighting Factor for each PB control variable $i$; and $\mathrm{N}_{i}$ is the normalization factor provided for by the European Commission (2016a) for each LCA IC linked with the PB control variable $i$.

The RED values are per definition dimensionless as both the LCA midpoint impacts and their associated normalization factors have the same unit. For communication purposes, the RED scores are expressed in the reference unit "RED points (RED Pt)", in line with approaches taken in other LCA single score indices (Frischknecht et al., 2009; Goedkoop, 2000). The RED points associated with a certain product or process then represent a specific environmental load: a higher score means a less sustainable outcome. 


\subsection{Case study: Environmental impact of meat consumption in Europe}

The environmental impacts from the study of Notarnicola and co-workers (2017) are calculated on a lifecycle basis, using the ILCD impact assessment method. Table S.1 (supplementary materials) lists the LCA impacts for the average apparent annual per capita consumption of each product within the EU basket, which are LCA outputs taken from that study. The case study presented here focuses on the three meat types contained within the basket. Based on this basket, the average European citizen annually consumes $13.7 \mathrm{~kg}$ beef, $41.0 \mathrm{~kg}$ pork and $22.9 \mathrm{~kg}$ poultry. This is a so-called apparent consumption, defined as Production + Import - Export, hence these numbers of apparent consumption do include food waste and losses along the food value chain and by consumers.

\subsubsection{Application \#1: Intercomparison of products}

After rescaling the LCA midpoint impacts for the three meat products to one portion (set at $125 \mathrm{~g}$ ), the associated RED score is calculated based on Eq. 6 .

\subsubsection{Application \#2: Comparison towards a reference value.}

Based on the LCA impact values from Table S.1, the RED score of the entire annual EU basket of products is calculated. This value is subsequently divided by 365 , resulting in the reference value "daily food consumption impact of a European citizen". The ratio of the RED score of 1 portion of meat $(125 \mathrm{~g})$ to this reference value shows the extent to which one portion of meat currently contributes the our daily RED score for food consumption.

We subsequently also looked at the protein content of the meat products using representative data of the USDA Food Composition Databases (USDA, 2016): $100 \mathrm{~g}$ of beef, pork and poultry respectively contain $22.12 \mathrm{~g}, 20.95 \mathrm{~g}$ and $20.85 \mathrm{~g}$ proteins. Chosen data records within the database are "Beef, tenderloin, steak, separable lean only, trimmed to $1 / 8$ " fat, all grades, raw", "Pork, fresh, loin, tenderloin, separable lean only, raw", and "Chicken, broilers or fryers, breast, meat and skin, raw". Based on this, the extent to which one portion of meat contributes to reaching our recommended daily protein intake in Belgium, set at $62 \mathrm{~g} /$ day for an average man, aged $18-59$ year (Hoge Gezondheidsraad, 2016) is calculated. 


\subsubsection{Application \#3: Scenario-analysis for changes in consumption patterns.}

Three alternative (hypothetical) meat consumption scenarios in the EU are investigated and compared with what is currently being consumed according to the EU basket (13.7 kg beef, $41.0 \mathrm{~kg}$ pork and $22.9 \mathrm{~kg}$ poultry per year). The alternative scenarios are based on a recent report which looks into how changing diets can contribute to more sustainability and more specifically, on those scenarios related to shifting away from beef (Ranganathan et al., 2016):

- Scenario 1 (SC1): ambitious beef reduction scenario reducing beef consumption levels to world consumption average, which leads to a reduction of $40 \%$ in Europe and to a reduction of total meat consumption within the EU basket from $77.6 \mathrm{~kg}$ to $72.1 \mathrm{~kg}$;

- Scenario 2 (SC2): shift from beef to pork and poultry, reducing beef consumption by $33 \%$ with a shift to an additional (equal) amount of pork and poultry being consumed, thus maintaining a total consumption of $77.6 \mathrm{~kg}$ of meat; and

- Scenario 3 (SC3): shift to consuming only poultry, maintaining a total consumption of $77.6 \mathrm{~kg}$.

\section{Results: application of the RED index to the environmental impact of}

\section{meat consumption in Europe}

\subsection{Application \#1: Intercomparison of products}

Table 3 shows in a step-by-step approach how Equation 6 was applied to the LCA results for one portion of meat. As shown in Figure 1, beef is the worst performer in the majority of LCA impact categories, and also has the highest RED score, far above that of pork and poultry.

\subsection{Application \#2: Comparison towards a reference value}

The total RED score for the annual consumption of food products as taken up in the food basket is 4.71 RED Pt (calculations not shown; see Table S.2 in the supplementary materials for the resulting RED scores). This results in a daily food consumption impact for a European citizen of 13 RED mPt (or 0.013 RED Pt). Figure 2 presents a visualization option for the RED index in the context of food products, showing how 
the RED score for one portion of meat $(125 \mathrm{~g})$ relates to the RED score for the daily food consumption of a European citizen and how this portion of meat contributes to our recommended daily protein intake.

One portion of beef represents $54 \%$ of the RED score for food consumption by a European citizen while contributing to $45 \%$ of our protein needs. One portion of pork and poultry on the other hand contributes to a much lower share of our daily RED score for food consumption (respectively 22 and 13\%) while still providing us with $42 \%$ of our recommended protein intake. The visualization is inspired by the Guideline Daily Amounts approach, as used for information provision to consumers on nutritional aspects (CIAA, 2009). Information is shown at a glance in contrast with the common (scientific) ways of presenting impact results, such as the graphs in Figure 1.

\subsection{Application \#3: Scenario-analysis for changes in consumption patterns}

The visualization in Figure 3 allows for easy identification of those options with greatest potential to reduce environmental impact while still providing us similar quantities of proteins. The alternative scenarios lead to more sustainable outcomes (SC1, SC2 and SC3 respectively lead to $15 \%$, $9 \%$ and $47 \%$ reductions of the total RED score associated with annual meat consumption) whereas protein levels have remained rather the same.

\section{Discussion}

\subsection{Weighting of LCA impacts}

The aspect of weighting and aggregating LCA impacts into one index is subject to debate. The ISO 14042 standard states that weighting shall not be used for comparative assertions disclosed to the public (ISO, 2006b) as weighting factors for aggregating LCA midpoint results are often based on value choices or on political targets. However, according to Brentrup and co-workers (2001) "weighting of the different impacts is indispensable to finally conclude on the environmental preference of one or the other alternative" when comparing products or processes. Moreover, if this step is not taken up, the user of the impact assessment would anyhow weigh the different impacts on his/her own and choose the relevant impact categories subjectively, or at least implicitly, as also concluded at the SETAC Europe $25^{\text {th }}$ Annual Meeting (Kägi et al., 2016; SETAC, 2015). Brentrup and co-authors (2001) therefore suggest applying a 
harmonized set of weighting factors to ensure a more unbiased aggregation of the impacts. As such, this paper proposes weighting factors based on scientific PB-based targets, rather than political ones or value targets, with the aim of bringing LCA results closer to non-experts in the LCA field.

\subsection{Using the PB-framework to develop weighting factors}

A distance-to-target approach has previously been applied by Tuomisto and co-workers (2012) to obtain PB-based weighting factors to convert LCA results. However, no distinction was made between upper and lower targets for the PB control variables, which leads to distorting weighting factors since a value higher than a maximum limit is considered equally bad as a value higher than a minimum limit. Additionally, the authors did not use a universal set of normalization factors, but rather divided each LCA impact result by the highest value obtained within this impact category for the products or systems under comparison which results in non-comparable results if applied to different sets of products to be compared. Finally, next to LCA midpoint impact results, the authors used LCA inventory data to calculate the aggregated single score impact, rather than LCA impact results. Yet, tracing back the raw data from the LCA inventory will in most cases be quite cumbersome or even impossible as it is often not readily available in published LCA results, hence not fulfilling the first requirement stated in the present research.

\subsection{Absolute versus comparative sustainability}

There is a growing interest in downscaling the global-scale PB concept to the levels of individuals, regions or countries (Häyhä et al., 2016; Hoff et al., 2014; Nykvist et al., 2013). In this context, several authors looked into developing PB-based characterization or normalization factors (Bjørn and Hauschild, 2015; Doka, 2015). Clift and co-workers (2017) further explored the challenges in operationalizing absolute sustainability through the PB framework approach, for application in industry or other organizations. The RED index developed within the context of this study is useful for comparative or relative sustainability assessments as it facilitates choosing the best available option in the context of reducing environmental impact. The weighting system the RED index is built on, uses the trespassing of the boundaries to express a sense of urgency. The resulting RED score is thus an accumulation of "sense of urgencies" which allows comparing similar products, creating a reference framework and analysing the environmental consequences of changes in consumption patterns. 


\subsection{Application of the RED index in the context of food consumption}

The case study illustrates how the index can be used within the context of assessing food choices or consumption patterns. Literature has seen a recent rise in papers investigating the environmental impact of food consumption and dietary changes, thereby reinforcing the relevance of the case study investigated (J. Davis et al., 2010; K.F. Davis et al., 2016; de Vries and de Boer, 2010; Dooren et al., 2017; Green et al., 2015; Heller et al., 2013; Reynolds et al., 2014; Roy et al., 2012; Sonesson et al., 2016; Stylianou et al., 2016; Tilman and Clark, 2014; Van Dooren et al., 2014; Westhoek et al., 2014).

The LCA results the case study is based on, use $\mathrm{kg}$ of food as a functional unit (FU). However, the RED approach is independent of the FU chosen. A such it can easily be applied to all sorts of LCA results, expressed in a wide range of FUs.

In the visualization of the case study, the RED index is put alongside protein content, allowing a more inclusive perspective on the environmental impacts of food consumption. Next to protein content or quality, other nutrient characteristics of foods should be taken into account for assessing the nutritional impact of a food product or of food consumption scenarios (van Dooren et al., 2017); this was however outside scope of this paper.

When it comes to the RED reference value, it should be noted that the daily RED score of a European citizen does not relate to a tipping point or to a sustainability threshold, but merely allows us to put consumption of a specific food product in the context of the entire food basket being consumed in a certain reference year and reference location. This in contrary to nutritional reference frameworks which refer to our nutritional needs, to what should be consumed. Altering the composition of the food basket would affect the daily RED score and thus affect the percentage contribution of consuming one portion of meat. A such, the results may differ across continents and/or as consumption patterns change. In case of consumption outside of Europe, we could think about developing a "world basket of products" on food consumption based on FAO data such as the FAO Food Consumption Database (FAO, n.d.), if possible. The index can further be used for LCA studies on any product or process, beyond food or consumer goods. In case the index would be used for non-food products, the reference value to compare the results with, would for example be based on the EU basket of products related to housing, mobility or consumer goods (EC-JRC, 2012). 
When it comes to scenario analysis, the scenarios would lead to changes in demand for one or more meat products, thus requiring a consequential LCA analysis (Ekvall et al., 2016; Sonnemann and Vigon, 2011). Since this was outside the scope of this paper, LCA results associated with the current consumption patterns within Europe were used throughout each scenario.

\subsection{Way forward}

The RED index is based on the current state of knowledge on planetary boundaries and we believe it can be an important step towards transparent communication about sustainability of products and processes to all members of society. For the future, several improvements can be envisaged. For example, to our knowledge, no consensus exists on the severity or comparability of crossing boundaries, while it is probable that the harm caused by having a species extinction rate twice the allowed rate is not equally severe or (ir)reversible as a phosphorous flow twice the allowed level. Similarly, crossing one of the socalled core planetary boundaries (climate change and biosphere integrity) may have more severe consequences than crossing the other boundaries. Future research could provide more insight in this and allow refinement of the RED index through the development of improved weighting factors.

The current weighting factors are based on the distance between the current value of the control variable and the associated boundary. This boundary refers to a threshold which should not be passed in order to prevent the Earth system to switch to another state. Next to using this tipping point as a reference, it could be interesting to also include the distance between the current value of the control variable and its natural level, resulting in an additional weighting factor. In the case of climate change for example, the natural level could then refer to the pre-industrial atmospheric $\mathrm{CO}_{2}$ concentration which ranges between 275 and 285 ppm (IPCC, 2007).

Another possible improvement for the RED index is through the inclusion of toxicity related impacts: such impacts are available in LCA results but could - for the moment - not be accounted for in the index as the PB control variables and boundaries for the novel entities earth system process are yet to be defined (Rockström et al., 2009a; Ryberg et al., 2016; Steffen et al., 2015). Similarly, the PB on biosphere integrity could for now not be linked to the LCA framework but work is ongoing on linking land use impacts with biodiversity (Chaudhary et al., 2015; Wilting et al., 2017).

Another hurdle to be tackled is the fact that the PB framework does not take into account resource use whereas sustainable resource management is a prerequisite for sustainable (food) production. Therefore, 
if we are to inform consumers on the environmental performance of (food) products, it could be interesting to also include the LCA impact category on mineral, fossil and renewable resource depletion in the index. The need to complement the PB framework with a measure on resource use was also acknowledged by Neill and co-workers (2018). In order to assess to what extent countries are using resources at a sustainable level, the authors complemented the boundaries presented in the PB framework with the maximum sustainable levels for the ecological and material footprint.

\section{Conclusions}

The study presents a novel index, the "Risk of earth Destabilization (RED) index" which aggregates readily available LCA midpoint impacts results from literature into a single score and allows for a clear visualization. Using weighting factors based on the Planetary Boundaries (PB) framework, the index takes into account the planetary urgency associated with each of the LCA impacts. The weighting factors developed within this study are based on scientifically valid targets, referring to both the boundaries set within the PB framework, as well as the uncertainty zone for each boundary. A case study on meat consumption in Europe illustrates the broad applicability of the RED index, which can, for example, be used for comparison of alike products, comparison towards a reference value or scenario-analysis for changes in consumption patterns. We believe our index provides a valuable contribution to the ongoing efforts on communicating to the general public on the environmental performance of products or processes. 


\section{Acknowledgments}

The authors greatly acknowledge the support of the Science, Engineering and Technology Group at KU Leuven for the Expertise Centre Ethics@Arenberg.

\section{References}

Benini, L., Mancini, L., Sala, S., Schau, E., Manfredi, S., Pant, R., 2014. Normalisation method and data for Environmental Footprints. JRC Technical reports. European Commission, Joint Research Centre (JRC-IES), Ispra, Italy.

Benini, L., Pant, R., Sala, S., 2015. Workshop: Environmental Footprint Weighting, 16.11.2015. Draft summary. European Commission, Brussels, Belgium.

Bjørn, A., Hauschild, M.Z., 2015. Introducing carrying capacity-based normalisation in LCA: framework and development of references at midpoint level. Int. J. Life Cycle Assess. 20, 1005-1018. doi:10.1007/s11367-015-0899-2

Brandão, M., Milà i Canals, L., Clift, R., 2011. Soil organic carbon changes in the cultivation of energy crops: Implications for GHG balances and soil quality for use in LCA. Biomass and Bioenergy 35, 2323-2336. doi:10.1016/j.biombioe.2009.10.019

Brentrup, F., Küsters, J., Kuhlmann, H., Lammel, J., 2004. Environmental impact assessment of agricultural production systems using the life cycle assessment methodology. I. Theoretical concept of a LCA method tailored to crop production. Eur. J. Agron. 20, 247-264. doi:10.1016/S1161-0301(03)00024-8

Brentrup, F., Küsters, J., Kuhlmann, H., Lammel, J., 2001. Application of the Life Cycle Assessment methodology to agricultural production: an example of sugar beet production with different forms of nitrogen fertilisers. Eur. J. Agron. 14, 221-233. doi:10.1016/S1161-0301(00)000988

Chaudhary, A., Verones, F., De Baan, L., Hellweg, S., 2015. Quantifying Land Use Impacts on Biodiversity: Combining Species-Area Models and Vulnerability Indicators. Environ. Sci. Technol. 49, 9987-9995. doi:10.1021/acs.est.5b02507

CIAA, 2009. GDAs: Guideline Daily Amounts. The Facts. Your choice. CIAA, FoodDrinkEurope, Brussels, Belgium.

Clift, R., Sim, S., King, H., Chenoweth, J., Christie, I., Clavreul, J., Mueller, C., Posthuma, L., Boulay, A.-M., Chaplin-Kramer, R., Chatterton, J., DeClerck, F., Druckman, A., France, C., Franco, A., Gerten, D., Goedkoop, M., Hauschild, M., Huijbregts, M., Koellner, T., Lambin, E., Lee, J., Mair, S., Marshall, S., McLachlan, M., Milà i Canals, L., Mitchell, C., Price, E., Rockström, J., Suckling, J., Murphy, R., 2017. The Challenges of Applying Planetary Boundaries as a Basis for Strategic Decision-Making in Companies with Global Supply Chains. Sustainability 9, 279. doi:10.3390/su9020279

Davis, J., Sonesson, U., Baumgartner, D.U., Nemecek, T., 2010. Environmental impact of four meals with different protein sources: Case studies in Spain and Sweden. Food Res. Int. 43, 1874-1884. doi:10.1016/j.foodres.2009.08.017 
Davis, K.F., Gephart, J.A., Emery, K.A., Leach, A.M., Galloway, J.N., D’Odorico, P., 2016. Meeting future food demand with current agricultural resources. Glob. Environ. Chang. 39, 125-132. doi:10.1016/j.gloenvcha.2016.05.004

de Vries, M., de Boer, I.J.M., 2010. Comparing environmental impacts for livestock products: A review of life cycle assessments. Livest. Sci. 128, 1-11. doi:10.1016/j.livsci.2009.11.007

de Vries, W., Kros, J., Kroeze, C., Seitzinger, S.P., 2013. Assessing planetary and regional nitrogen boundaries related to food security and adverse environmental impacts. Curr. Opin. Environ. Sustain. 5, 392-402. doi:10.1016/j.cosust.2013.07.004

Doka, G., 2015. Combining life cycle inventory results with planetary boundaries: The Planetary Boundary Allowance impact assessment method PBA'05. Doka LCA, Zurich, Switserland.

Doney, S.C., Mahowald, N., Lima, I., Feely, R.A., Mackenzie, F.T., Lamarque, J.F., Rasch, P.J., 2007. Impact of anthropogenic atmospheric nitrogen and sulfur deposition on ocean acidification and the inorganic carbon system. Proc Natl Acad Sci U S A 104, 14580-14585.

Dooren, C. Van, Douma, A., Aiking, H., Vellinga, P., 2017. Proposing a Novel Index Reflecting Both Climate Impact and Nutritional Impact of Food Products. Ecol. Econ. 131, 389-398. doi:10.1016/j.ecolecon.2016.08.029

EC-JRC, 2012. Life cycle indicators basket-of-products: development of life cycle based macrolevel monitoring indicators for resources, products and waste for the EU-27. European Commission, Joint Research Centre (JRC-IES), Ispra, Italy. doi:10.2788/50285

EC-JRC, 2011. ILCD Handbook: Recommendations for Life Cycle Impact Assessment in the European context. European Commission, JRC-IES, Ispra, Italy. doi:10.278/33030

EC-JRC, 2010. ILCD Handbook: Analysis of existing Environmental Impact Assessment methodologies for use in Life Cycle Assessment. Background document.

Ekvall, T., Azapagic, A., Finnveden, G., Rydberg, T., Weidema, B.P., Zamagni, A., 2016. Attributional and consequential LCA in the ILCD handbook. Int. J. Life Cycle Assess. 293-296. doi:10.1007/s11367-015-1026-0

European Commission, 2016a. Guidance for the implementation of the EU Product Environmental Footprint (PEF) during the Environmental Footprint (EF) pilot phase. Version 5.2, February 2016. European Commission, Brussels, Belgium.

European Commission, 2016b. Product Environmental Footprint Guidance. Guidance for the development of Product Environmental Footprint Category Rules (PEFCRs), Version 6.0, November 2016. European Commission, Brussels, Belgium.

European Commission, 2013. Commission Recommendation of 9 April 2013 on the use of common methods to measure and communicate the life cycle environmental performance of products and organisations (2013/179/EU). European Commission, Brussels, Belgium.

FAO, n.d. FAO Food Consumption Database. Food and Agriculture Organisation, Rome, Italy [WWW Document]. URL http://www.fao.org/nutrition/assessment/food-consumptiondatabase/en/ (accessed 2.7.17).

Frischknecht, R., Steiner, R., Jungbluth, N., 2009. The Ecological Scarcity Method. Eco-factors 2006. Environmental studies no. 0906. FOEN, Bern, Switzerland.

Goedkoop, M., 2000. Eco-indicator 99 Manual for Designers. VROM, The Netherlands.

Goedkoop, M., Heijungs, R., Huijbregts, M., Schryver, A. De, Struijs, J., Zelm, R. Van, 2013. ReCiPe 2008. A life cycle impact assessment method which comprises harmonised category indicators at the midpoint and the endpoint level. First edition. Report I: Characterisation. 
RIVM, The Netherlands.

Green, R., Milner, J., Dangour, A.D., Haines, A., Chalabi, Z., Markandya, A., Spadaro, J., Wilkinson, P., 2015. The potential to reduce greenhouse gas emissions in the UK through healthy and realistic dietary change. Clim. Change 129, 253-265. doi:10.1007/s10584-015-1329-y

Hauschild, M.Z., Goedkoop, M., Guinée, J., Heijungs, R., Huijbregts, M., Jolliet, O., Margni, M., De Schryver, A., Humbert, S., Laurent, A., Sala, S., Pant, R., 2013. Identifying best existing practice for characterization modeling in life cycle impact assessment. Int. J. Life Cycle Assess. 18, 683-697. doi:10.1007/s11367-012-0489-5

Häyhä, T., Lucas, P.L., Vuuren, D.P. Van, Cornell, S.E., Hoff, H., 2016. From Planetary Boundaries to national fair shares of the global safe operating space - How can the scales be bridged ? Glob. Environ. Chang. 40, 60-72. doi:10.1016/j.gloenvcha.2016.06.008

Heller, M.C., Keoleian, G.A., Willett, W.C., 2013. Toward a life cycle-based, diet-level framework for food environmental impact and nutritional quality assessment: A critical review. Environ. Sci. Technol. 47, 12632-12647. doi:10.1021/es4025113

Hoff, H., Nykvist, B., Carson, M., 2014. "Living well, within the limits of our planet"? Measuring Europe's growing external footprint. SEI WP 2014-05. Stockholm Environment Institute (SEI), Sweden.

Hoge Gezondheidsraad, 2016. Voedingsaanbevelingen voor België - 2016, Advies nr. 9285. Brussel, Belgium.

Huppes, G., Oers, L. Van, 2011. Background Review of Existing Weighting Approaches in Life Cycle Impact Assessment (LCIA). European Commission, JRC-IES, Ispra, Italy.

IPCC, 2007. Climate Change 2007: The Physical Science Basis. Contribution of Working Group I to the Fourth Assessment Report of the Intergovernmental Panel on Climate Change. Chapter 2: Changes in Atmospheric Constituents and in Radiative Forcing. Cambridge University Press, Cambridge, United Kingdom and New York, NY, USA.

ISO, 2006a. ISO 14040 Environmental management - Life cycle assessment - Principles and framework (ISO 14040:2006(E)). ISO, International Organization for Standardization.

ISO, 2006b. ISO 14044 Environmental management - Life cycle assessment - Requirements and guidelines (ISO 14044:2006(E)). ISO, International Organization for Standardization.

Kägi, T., Dinkel, F., Frischknecht, R., Humbert, S., Lindberg, J., De Mester, S., Ponsioen, T., Sala, S., Schenker, U.W., 2016. Session “Midpoint, endpoint or single score for decision-making?" SETAC Europe 25th Annual Meeting, May 5th, 2015. Int. J. Life Cycle Assess. 21, 129-132. doi:10.1007/s11367-015-0998-0

Milà i Canals, L., Romanyà, J., Cowell, S.J., 2007. Method for assessing impacts on life support functions (LSF) related to the use of "fertile land" in Life Cycle Assessment (LCA). J. Clean. Prod. 15, 1426-1440. doi:10.1016/j.jclepro.2006.05.005

Neill, D.W.O., Fanning, A.L., Lamb, W.F., Steinberger, J.K., 2018. A good life for all within planetary boundaries. Nat. Sustain. 1. doi:10.1038/s41893-018-0021-4

Notarnicola, B., Tassielli, G., Renzulli, P.A., Castellani, V., Serenella, S., 2017. Environmental impacts of food consumption in Europe. J. Clean. Prod. 140, 753-765.

Nykvist, B., Persson, Å., Moberg, F., Persson, L., Cornell, S., Rockström, J., 2013. National Environmental Performance on Planetary Boundaries - A study for the Swedish Environmental Protection Agency. Swedish Environmental Protection Agency. doi:ISBN 97891-620-6576-8 
Pré, 2017. SimaPro Database Manual. Methods library. doi:10.1017/CBO9781107415324.004

Ranganathan, J., Vennard, D., Waite, R., Dumas, P., Lipinski, B., Searchinger, T., 2016. Shifting diets for a sustainable future. Installment 11 of "Creating a Sustainable Food Future". Working paper. World Resources Institute (WRI), US.

Redfield, A.C., Ketchum, B.H., Richards, F.A., 1963. The influence of organisms on the composition of sea water, in: Hill M N (Ed.), The Sea: Ideas and Observations on Progress in the Study of the Seas. Volume 2. The Composition of Seawater: Comparative and Descriptive Oceanography. pp. 26-77.

Reynolds, C.J., David Buckley, J., Weinstein, P., Boland, J., 2014. Are the dietary guidelines for meat, fat, fruit and vegetable consumption appropriate for environmental sustainability? A review of the literature. Nutrients 6, 2251-2265. doi:10.3390/nu6062251

Rockström, J., Steffen, W., Noone, K., Persson, Å., Chapin, F.S., Lambin, E., Lenton, T.M., Scheffer, M., Folke, C., Schellnhuber, H.J., Nykvist, B., de Wit, C. a., Hughes, T., van der Leeuw, S., Rodhe, H., Sörlin, S., Snyder, P.K., Costanza, R., Svedin, U., Falkenmark, M., Karlberg, L., Corell, R.W., Fabry, V.J., Hansen, J., Walker, B., Liverman, D., Richardson, K., Crutzen, P., Foley, J., 2009a. Planetary boundaries: Exploring the safe operating space for humanity. Ecol. Soc. 14, 32. doi:10.1038/461472a

Rockström, J., Steffen, W., Noone, K., Persson, Å., Chapin, F.S., Lambin, E., Lenton, T.M., Scheffer, M., Folke, C., Schellnhuber, H.J., Nykvist, B., de Wit, C. a., Hughes, T., van der Leeuw, S., Rodhe, H., Sörlin, S., Snyder, P.K., Costanza, R., Svedin, U., Falkenmark, M., Karlberg, L., Corell, R.W., Fabry, V.J., Hansen, J., Walker, B., Liverman, D., Richardson, K., Crutzen, P., Foley, J., 2009b. A safe operating space for humanity. Nature 461. doi:472-475 DOI $10.1038 / 461472 a$

Roy, P., Orikasa, T., Thammawong, M., Nakamura, N., Xu, Q., Shiina, T., 2012. Life cycle of meats: An opportunity to abate the greenhouse gas emission from meat industry in Japan. J. Environ. Manage. 93, 218-224. doi:10.1016/j.jenvman.2011.09.017

Ryberg, M.W., Owsianiak, M., Richardson, K., Hauschild, M.Z., 2016. Challenges in implementing a Planetary Boundaries based Life-Cycle Impact Assessment methodology. J. Clean. Prod. 139, 450-459. doi:http://dx.doi.org/10.1016/j.jclepro.2016.08.074

SETAC, 2015. Session: Midpoint or single score for decision making (I), in: Environmental Protection in a Multi-Stressed World: Challenges for Science, Industry and Regulators. Abstract Book. SETAC Europe 25th Annual Meeting, 3-7 May 2015, Barcelona, Spain. SETAC Europe Office, Brussels, Belgium, pp. 64-65. doi:10.1017/CBO9781107415324.004

Sleeswijk, A.W., van Oers, L.F.C.M., Guinée, J.B., Struijs, J., Huijbregts, M. a. J., 2008. Normalisation in product life cycle assessment: An LCA of the global and European economic systems in the year 2000. Sci. Total Environ. 390, 227-240. doi:10.1016/j.scitotenv.2007.09.040

Sonesson, U., Davis, J., Flysjö, A., Gustavsson, J., Witthöft, C., 2016. Protein quality as functional unit - a methodological framework for inclusion in life cycle assessment of food. J. Clean. Prod. 140, 1-9. doi:10.1016/j.jclepro.2016.06.115

Sonnemann, G., Vigon, B., 2011. Global guidance principles for Life Cycle Assessment databases. A basis for greener processes and products. "Shonan Guidance Principles." UNEP/SETAC Life Cycle Initiative, Paris, France.

Steffen, W., Richardson, K., Rockström, J., Cornell, S.E., Fetzer, I., Bennett, E.M., Biggs, R., 
Carpenter, S.R., de Vries, W., de Wit, C.A., Folke, C., Gerten, D., Heinke, J., Mace, G.M., Persson, L.M., Ramanathan, V., Reyers, B., Sörlin, S., 2015. Planetary boundaries: Guiding human development on a changing planet. Science (80-. ). 347, 1259855. doi:10.1126/science.1259855

Stylianou, K.S., Heller, M.C., Fulgoni, V.L., Ernstoff, A.S., Keoleian, G.A., Jolliet, O., 2016. A life cycle assessment framework combining nutritional and environmental health impacts of diet: a case study on milk. Int. J. Life Cycle Assess. 21, 734-746. doi:10.1007/s11367-0150961-0

Tilman, D., Clark, M., 2014. Global diets link environmental sustainability and human health. Nature 515, 518-522. doi:10.1038/nature13959

Tuomisto, H.L., Hodge, I.D., Riordan, P., MacDonald, D.W., 2012. Exploring a safe operating approach to weighting in life cycle impact assessment - A case study of organic, conventional and integrated farming systems. J. Clean. Prod. 37, 147-153. doi:10.1016/j.jclepro.2012.06.025

USDA, 2016. US Department of Agriculture, Agricultural Research Service, Nutrient Data Laboratory. USDA National Nutrient Database for Standard Reference, Release 28. Version Current: May 2016. [WWW Document]. URL https://ndb.nal.usda.gov/ndb/search/list (accessed 12.5.16).

van Dooren, C., Douma, A., Aiking, H., Vellinga, P., 2017. Proposing a Novel Index Reflecting Both Climate Impact and Nutritional Impact of Food Products. Ecol. Econ. 131, 389-398. doi:10.1016/j.ecolecon.2016.08.029

Van Dooren, C., Marinussen, M., Blonk, H., Aiking, H., Vellinga, P., 2014. Exploring dietary guidelines based on ecological and nutritional values: A comparison of six dietary patterns. Food Policy 44, 36-46. doi:10.1016/j.foodpol.2013.11.002

Westhoek, H., Peter, J., Rood, T., Wagner, S., Marco, A. De, Murphy-bokern, D., Leip, A., Grinsven, H. Van, Sutton, M.A., Oenema, O., 2014. Food choices, health and environment: Effects of cutting Europe's meat and dairy intake. Glob. Environ. Chang. 26, 196-205. doi:10.1016/j.gloenvcha.2014.02.004

Wilting, H.C., Schipper, A.M., Bakkenes, M., Meijer, J.R., Huijbregts, M.A.J., 2017. Quantifying Biodiversity Losses Due to Human Consumption : A Global-Scale Footprint Analysis. Environ. Sci. Technol. 51, 3298-3306. doi:10.1021/acs.est.6b05296 
Figure 1 Case study - Intercomparison of products. Visual representation of the conversion of ILCD LCA impacts for meat consumption in Europe into the Risk of Earth Destabilization (RED) index for 1 portion (125g) of beef, pork and poultry. (A) Typical scientific visualization of LCA impacts (based on Notarnicola et al. (2017)) expressed relative to the worst performing product. (B) Visualization of the resulting RED scores (in RED points) whereby the colours of the contributing Planetary Boundaries earthsystem processes correspond to those of the LCA impact categories (from part A) they were linked to.

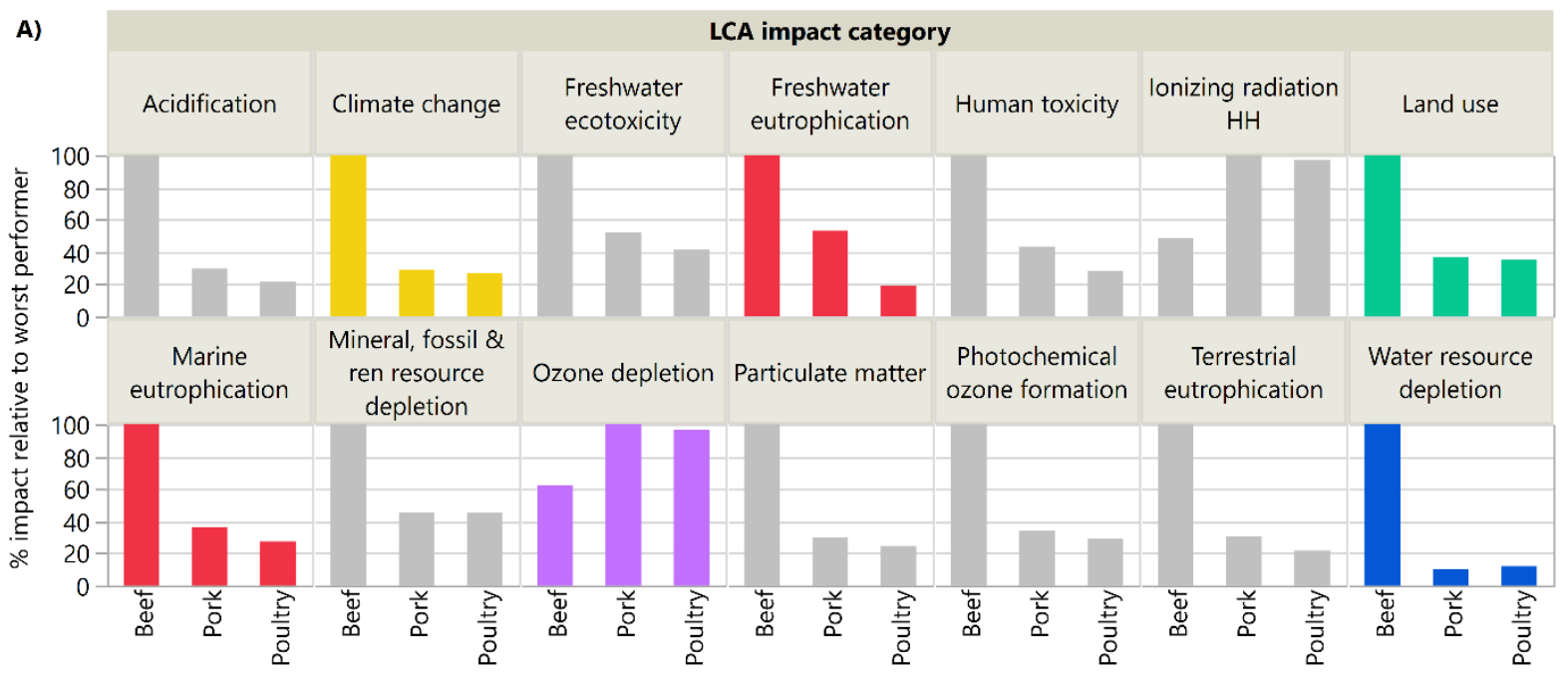

B)

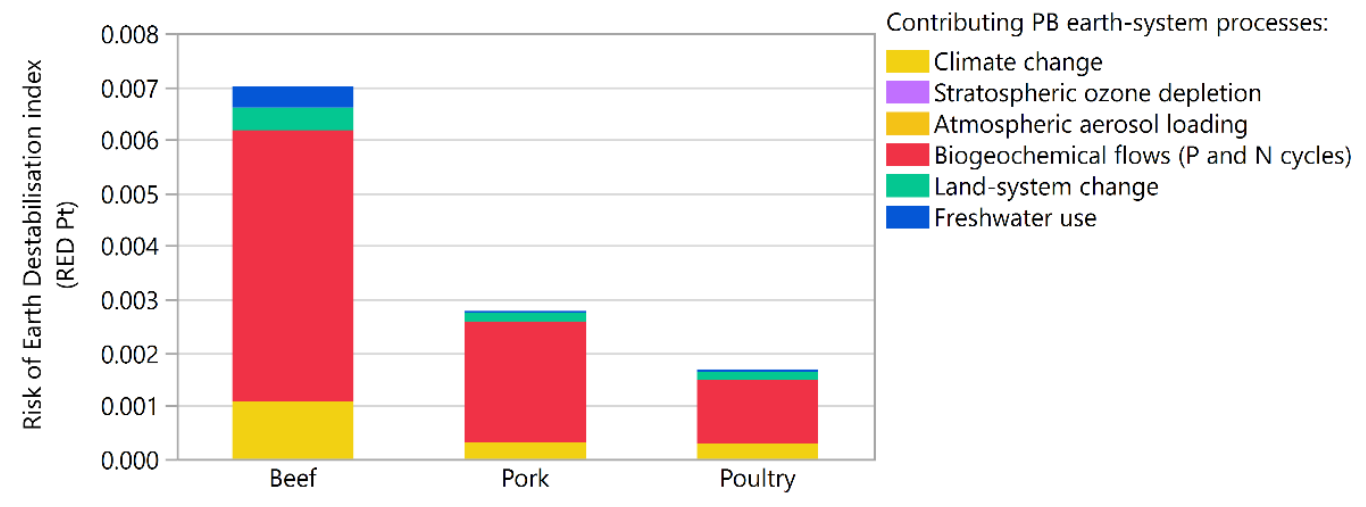


Figure 2 Case study - Comparison towards a reference value. Visualization of the contribution of one portion (125g) of beef, pork and poultry to our recommended daily protein intake (set at $62 \mathrm{~g} /$ day (Hoge Gezondheidsraad, 2016)) and to our daily Risk of Earth Destabilization (RED) score for food consumption (calculated as the RED score for daily food consumption by an average European citizen, expressed in RED milli-points). This visualization is inspired by the Guideline Daily Amounts approach, as used for information provision to consumers on nutritional aspects.
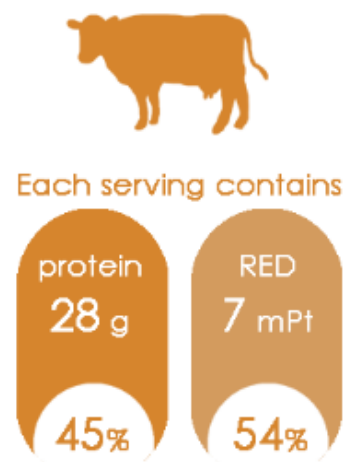

$\begin{array}{cc}\text { Of an adult's } & \text { Of an adult's } \\ \text { recommended } & \text { daily RED } \\ \text { daily protein } & \text { score }\end{array}$

intake
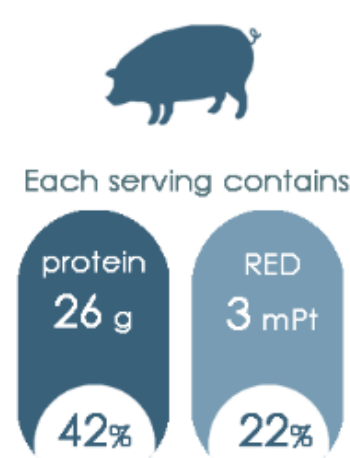

Of an adult's $\begin{gathered}\text { Of an adult's } \\ \text { daily RED }\end{gathered}$
recommended
daily protein
score intake



Each serving contains

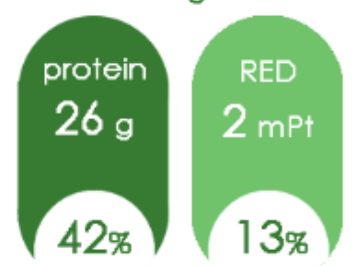
Of an adult's
Of an adult's
recommended
daily RED
scoily protein 
Figure 3 Case study- Scenario-analysis and transparent visualization for dietary patterns related to meat consumption. The current annual consumption volumes, as taken up in the EU basket (i.e., $13.7 \mathrm{~kg}$ beef, $41 \mathrm{~kg}$ pork and $22.9 \mathrm{~kg}$ poultry (Notarnicola et al., 2017)), are used as reference scenario. "SC1" refers to reduction of beef consumption by $40 \%$ to world consumption average; "SC2" to reduction of beef consumption by $33 \%$ with a shift to pork and poultry; and "SC3" to a shift to consuming only poultry. For each scenario, the figure shows (from left to right): the total annual per capita meat consumption (kg), the annual consumption ( $\mathrm{kg}$ ) per meat type, and a visualization of the protein intake and the Risk of Earth Destabilization (RED) score (expressed in RED points), as well as how they relate to respectively the recommended protein intake per year and the RED score for the average annual food consumption by a European citizen.

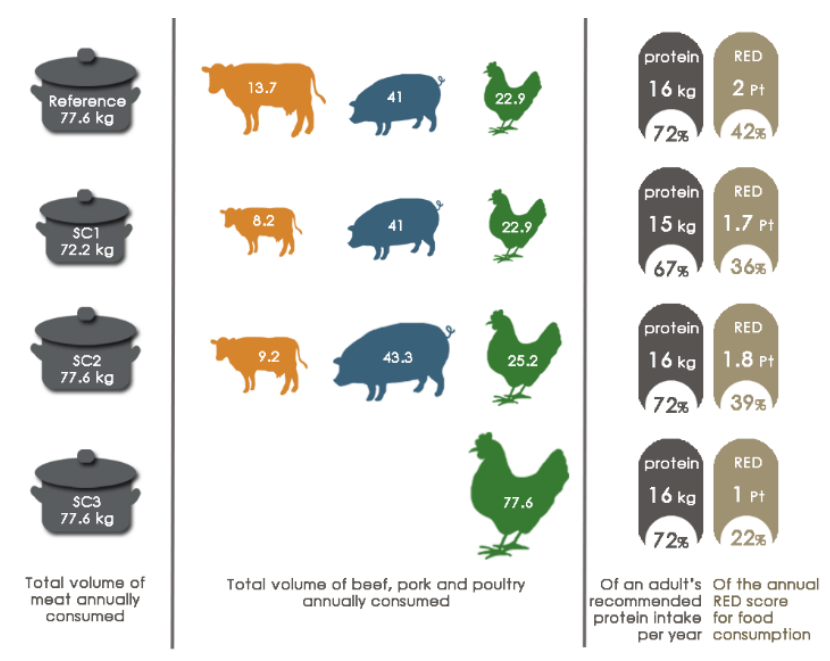


Table 1. Overview of the planetary boundaries framework, based on Steffen et al. (2015). Earth system processes, control variables, set planetary boundaries (PB) and zone of uncertainty, and current value of control variable, taken from Steffen et al. (2015). For the purpose of the present research, we added the traffic light colour coding. a

\begin{tabular}{|c|c|c|c|c|c|c|}
\hline Earth system process & Control variable & PB & $\begin{array}{l}\text { PB zone of } \\
\text { uncertainty }\end{array}$ & $\begin{array}{l}\text { Nature } \\
\text { of limit }\end{array}$ & $\begin{array}{l}\text { Current } \\
\text { value }\end{array}$ & Unit \\
\hline \multirow[t]{2}{*}{ Climate change } & Atmospheric carbon dioxide $\left(\mathrm{CO}_{2}\right)$ concentration & 350 & $350-450$ & Upper & 398.5 & $\mathrm{ppm} \mathrm{CO} 2$ \\
\hline & Energy imbalance of top of atmosphere & 1.0 & $1-1.5$ & Upper & 2.3 & $\mathrm{~W} / \mathrm{m}^{2}$ \\
\hline \multirow[t]{2}{*}{$\begin{array}{l}\text { Change in biosphere } \\
\text { integrity }\end{array}$} & Genetic diversity: extinction rate & $10^{b}$ & $10-100$ & Upper & $100-1000$ & $\begin{array}{l}\text { E/MSY (extinctions per } \\
\text { million species-years) }\end{array}$ \\
\hline & Functional biodiversity: Biodiversity intactness index & $90^{c}$ & $90-30$ & Lower & 84 & $\%$ \\
\hline $\begin{array}{l}\text { Stratospheric ozone } \\
\text { depletion }\end{array}$ & Stratospheric ozone $\left(\mathrm{O}_{3}\right)$ concentration & 275.5 & $275.5-261$ & Lower & 283 & DU (Dobson units) \\
\hline Ocean acidification & $\begin{array}{l}\text { Carbonate ion concentration, average global surface } \\
\text { ocean saturation state with respect to aragonite }\end{array}$ & 80 & $80-70$ & Lower & 84 & $\begin{array}{l}\% \text { of the pre-industrial } \\
\text { aragonite saturation } \\
\text { state, including } \\
\text { natural diel and } \\
\text { seasonal variability }\end{array}$ \\
\hline \multirow[t]{3}{*}{$\begin{array}{l}\text { Biogeochemical flows } \\
\text { (P and } \mathrm{N} \text { cycles) }\end{array}$} & $\begin{array}{l}\text { Phosphorous (P) Global: P flow from freshwater systems } \\
\text { into the ocean }\end{array}$ & 11 & $11-100$ & Upper & 22 & $\operatorname{Tg} \mathrm{P} /$ year \\
\hline & $\begin{array}{l}\text { Phosphorous (P) Regional: P flow from fertilizers to } \\
\text { erodible soils }\end{array}$ & 6.2 & $6.2-11.2$ & Upper & 14 & $\operatorname{Tg} \mathrm{P} /$ year \\
\hline & $\begin{array}{l}\text { Nitrogen }(N) \text { Global: Industrial and intentional biological } \\
\text { fixation of } N\end{array}$ & 62 & $62-82$ & Upper & 150 & $\operatorname{Tg} \mathrm{N} /$ year \\
\hline \multirow[t]{2}{*}{ Land-system change } & Global: Area of forested land as \% of original forest cover & 75 & $75-54$ & Lower & 62 & $\%$ \\
\hline & Biome: Area of forested land as \% of potential forest & $50^{d}$ & $50-30$ & Lower & - & $\%$ \\
\hline \multirow[t]{2}{*}{ Freshwater use } & Global: Maximum amount of consumptive blue water use & 4000 & $4000-6000$ & Upper & 2600 & $\mathrm{~km}^{3} /$ year \\
\hline & $\begin{array}{l}\text { Basin: Blue water withdrawal as } \% \text { of mean monthly river } \\
\text { flow }\end{array}$ & $30^{\mathrm{e}}$ & $30-60$ & Upper & - & $\%$ \\
\hline \multirow{3}{*}{$\begin{array}{l}\text { Atmospheric aerosol } \\
\text { loading } \\
\text { Introduction of novel } \\
\text { entities }\end{array}$} & Global: Aerosol Optical Depth (AOD) & - & - & - & - & AOD \\
\hline & Regional: $A O D$ as a seasonal average over a region & $0.25^{f}$ & $0.25-0.50$ & Upper & 0.30 & AOD \\
\hline & Not defined yet & - & - & - & - & - \\
\hline
\end{tabular}


${ }^{a}$ The colour scheme for the current value of the control variable indicates its status: green = not surpassed the PB ("safe"); orange = surpassed the PB but within zone of uncertainty of the proposed PB ("increasing risk"); red = surpassed both the PB and its zone of uncertainty ("high risk"). In case the PB control variables differ per region, the value that would be most suitable for Europe was chosen, as indicated in the table.

${ }^{b}$ With an aspirational goal of $1 \mathrm{E} / \mathrm{MSY}$.

${ }^{c}$ PB threshold is applicable to Southern Africa only.

d PB for temperate regions.

e PB for intermediate flow months.

${ }^{f}$ No global quantification available: South Asian Monsoon used as a case study, thus only applicable to the South Asian region. This explains why its trespassing of the boundary (status = orange) does not count towards the number of boundaries that have been trespassed globally, leading to a total count of four in Steffen et al. (2015) 
Table 2 Overview of the earth system processes and control variables from the Planetary Boundaries (PB) framework that could be linked to the LCA framework, and the resulting weighting factors (WF) for each one of them. Traffic light colour coding from Table 1 was applied to the WFs to facilitate interpretation of their magnitude.

\begin{tabular}{|c|c|c|c|c|c|}
\hline PB Earth system process & PB Control variable & LCA impact category (unit) & WFBoundary & WFuncertainty & WFrED \\
\hline Climate change & $\begin{array}{l}\text { Energy imbalance of top of } \\
\text { atmosphere }\end{array}$ & $\begin{array}{l}\text { Climate change } \\
(\mathrm{kg} \mathrm{CO} 2 \mathrm{eq})\end{array}$ & 2.3 & 1.5 & 3.5 \\
\hline $\begin{array}{l}\text { Stratospheric ozone } \\
\text { depletion }\end{array}$ & Stratospheric $\mathrm{O}_{3}$ concentration & $\begin{array}{l}\text { Ozone depletion } \\
\text { (kg CFC-11 eq) }\end{array}$ & 0.97 & 1.0 & 0.97 \\
\hline \multirow[t]{3}{*}{$\begin{array}{l}\text { Biogeochemical flows } \\
\text { (P and } \mathrm{N} \text { cycles) }\end{array}$} & $\begin{array}{l}\text { P Global: P flow from freshwater } \\
\text { systems into the ocean }\end{array}$ & $\begin{array}{l}\text { Marine eutrophication } \\
\text { (kg N eq) }\end{array}$ & 2.0 & 1.0 & 2.0 \\
\hline & $\begin{array}{l}\text { P Regional: P flow from fertilizers } \\
\text { to erodible soils }\end{array}$ & $\begin{array}{l}\text { Freshwater eutrophication } \\
\text { (kg P eq) }\end{array}$ & 2.3 & 1.3 & 2.8 \\
\hline & $\begin{array}{l}\text { N Global: Industrial and } \\
\text { intentional biological fixation of } \mathrm{N}\end{array}$ & $\begin{array}{l}\text { Freshwater eutrophication } \\
\text { (kg P eq) }\end{array}$ & 2.4 & 1.8 & 4.4 \\
\hline Land-system change & $\begin{array}{l}\text { Global: Area of forested land as } \% \\
\text { of original forest cover }\end{array}$ & $\begin{array}{l}\text { Land use } \\
\text { (kg C deficit) }\end{array}$ & 1.2 & 1.0 & 1.2 \\
\hline Freshwater use & $\begin{array}{l}\text { Global: Maximum amount of } \\
\text { consumptive blue water use }\end{array}$ & $\begin{array}{l}\text { Water resource depletion } \\
\left(\mathrm{m}^{3} \text { water eq) }\right.\end{array}$ & 0.65 & 1.0 & 0.65 \\
\hline
\end{tabular}


Table 3 Case study - Intercomparison of meat products consumed in Europe showing the different steps throughout the process of calculating the RED score for 1 portion of beef, pork or poultry based on Equation 6. The LCA impacts are based on the EU food basket of products (Notarnicola et al., 2017); the LCA normalisation factors are those provided for by the European Commission (2016). The colours used for the Weighting Factors (WFs) follow the traffic colour coding used in Table 1 and Table 2. In case more than one PB control variable was linked to an LCA IC, the sum of the RED Weighting Factors for each control variable was used for the calculations. This was the case for the P regional and $\mathrm{N}$ global control variables which were both linked to the LCA IC freshwater eutrophication, resulting in a final WF $F_{\text {RED }}$ of $7.2(=2.8+4.4)$.

\begin{tabular}{|c|c|c|c|c|c|c|c|c|}
\hline \multicolumn{6}{|c|}{ Components of Eq. 6.6} & \multirow{2}{*}{\multicolumn{2}{|c|}{$\begin{array}{l}\text { Intermediate result } \\
\text { RED score prior to } \\
\text { aggregation }\end{array}$}} & \multirow{2}{*}{$\begin{array}{c}\text { Final result } \\
\text { Aggregated } \\
\text { RED score }\end{array}$} \\
\hline \multicolumn{3}{|c|}{ LCA impacts for consumption of 1 portion (125 g) } & \multicolumn{2}{|c|}{ LCA normalisation factor $\mathbf{N}$} & \multirow{2}{*}{$\begin{array}{c}\mathbf{W} \mathbf{F}_{\text {RED }} \\
3.5\end{array}$} & & & \\
\hline Climate change & 28 & $10^{-1} \mathrm{~kg} \mathrm{CO}_{2}$ eq & 9.2 & $10^{3} \mathrm{~kg} \mathrm{CO}_{2} \mathrm{eq}$ & & 11 & $10^{-4}$ RED Pt & \multirow{6}{*}{$\begin{array}{c}7.0 \\
* 10^{-3} \text { RED } \\
\text { Pt }\end{array}$} \\
\hline Ozone depletion & 7.4 & $10^{-9} \mathrm{~kg}$ CFC-11 eq & 2.2 & $10^{-2} \mathrm{~kg}$ CFC-11 eq & 0.97 & 3.3 & $10^{-7}$ RED Pt & \\
\hline Marine eutrophication & 22 & $10^{-3} \mathrm{~kg} \mathrm{~N}$ eq & 1.7 & $10 \mathrm{~kg} \mathrm{~N}$ eq & 2.0 & 26 & $10^{-4}$ RED Pt & \\
\hline Freshwater eutrophication & 51 & $10^{-5} \mathrm{~kg} P$ eq & 1.5 & kg P eq & 7.2 & 25 & $10^{-4}$ RED Pt & \\
\hline Land use & 26 & $\mathrm{~kg} C$ deficit & 7.5 & $10^{4} \mathrm{~kg} \mathrm{C}$ deficit & 1.2 & 4.3 & $10^{-4}$ RED Pt & \\
\hline Water resource depletion & 50 & $10^{-3} \mathrm{~m}^{3}$ water eq & 8.1 & $10 \mathrm{~m}^{3}$ water eq & 0.65 & 40 & $10^{-5}$ RED Pt & \\
\hline Climate change & 8.2 & $10^{-1} \mathrm{~kg} \mathrm{CO}_{2} \mathrm{eq}$ & 9.2 & $10^{3} \mathrm{~kg} \mathrm{CO}_{2}$ eq & 3.5 & 3.1 & $10^{-4}$ RED Pt & \multirow{6}{*}{$\begin{array}{c}2.8 \\
* 10^{-3} \text { RED } \\
\text { Pt }\end{array}$} \\
\hline Ozone depletion & 12 & $10^{-9} \mathrm{~kg}$ CFC-11 eq & 2.2 & $10^{-2} \mathrm{~kg}$ CFC-11 eq & 0.97 & 5.4 & $10^{-7}$ RED Pt & \\
\hline Marine eutrophication & 7.9 & $10^{-3} \mathrm{~kg} \mathrm{~N}$ eq & 1.7 & $10 \mathrm{~kg} \mathrm{~N} \mathrm{eq}$ & 2.0 & 9.4 & $10^{-4}$ RED Pt & \\
\hline Freshwater eutrophication & 27 & $10^{-5} \mathrm{~kg} P$ eq & 1.5 & kg P eq & 7.2 & 13 & $10^{-4}$ RED Pt & \\
\hline Land use & 9.8 & kg C deficit & 7.5 & $10^{4} \mathrm{~kg} C$ deficit & 1.2 & 1.6 & $10^{-4}$ RED Pt & \\
\hline Water resource depletion & 5.2 & $10^{-3} \mathrm{~m}^{3}$ water eq & 8.1 & $10 \mathrm{~m}^{3}$ water eq & 0.65 & 4.1 & $10^{-5}$ RED Pt & \\
\hline Climate change & 7.6 & $10^{-1} \mathrm{~kg} \mathrm{CO}_{2}$ eq & 9.2 & $10^{3} \mathrm{~kg} \mathrm{CO}_{2}$ eq & 3.5 & 2.9 & $10^{-4}$ RED Pt & \multirow{6}{*}{$\begin{array}{c}1.7 \\
* 10^{-3} \text { RED } \\
\text { Pt }\end{array}$} \\
\hline Ozone depletion & 11 & $10^{-9} \mathrm{~kg}$ CFC-11 eq & 2.2 & $10^{-2} \mathrm{~kg}$ CFC-11 eq & 0.97 & 5.2 & $10^{-7}$ RED Pt & \\
\hline Marine eutrophication & 6.0 & $10^{-3} \mathrm{~kg} \mathrm{~N}$ eq & 1.7 & $10 \mathrm{~kg} \mathrm{~N} \mathrm{eq}$ & 2.0 & 7.1 & $10^{-4}$ RED Pt & \\
\hline Freshwater eutrophication & 9.8 & $10^{-5} \mathrm{~kg} P$ eq & 1.5 & kg P eq & 7.2 & 4.8 & $10^{-4}$ RED Pt & \\
\hline Land use & 9.3 & kg C deficit & 7.5 & $10^{4} \mathrm{~kg} \mathrm{C}$ deficit & 1.2 & 1.5 & $10^{-4}$ RED Pt & \\
\hline Water resource depletion & 6.0 & $10^{-3} \mathrm{~m}^{3}$ water eq & 8.1 & $10 \mathrm{~m}^{3}$ water eq & 0.65 & 4.8 & $10^{-5}$ RED Pt & \\
\hline
\end{tabular}




\section{SUPPLEMENTARY MATERIALS}

The Risk of Earth Destabilization (RED) index, aggregating the impact we make and what the planet can take

Yanne Goossens ${ }^{a}$, Johan De Tavernier ${ }^{b}$, Annemie Geeraerd ${ }^{a}{ }^{*}$

${ }^{a}$ KU Leuven, Faculty Bioscience Engineering, Department of Biosystems (Division MeBioS) and Ethics@Arenberg, W. de Croylaan 42 box 2428, B-3001 Leuven, Belgium.

b KU Leuven, Ethics@Arenberg, Sint-Michielsstraat 4 - box 3101, B-3000 Leuven, Belgium.

* Corresponding Author: annemie.geeraerd@kuleuven.be 


\section{Case study - LCA impacts for EU food consumption}

The EU basket gathers products that are believed to be representative for food consumption for the year 2010 in Europe: EU apparent consumption data was first divided into main food categories, after which the food products with the largest apparent consumption in terms of mass and economic value were included in the basket.

Table S.1 lists the LCA impacts for the average apparent annual per capita consumption of each product within the EU basket, taken from Notarnicola and co-workers (2017). Based on this basket, the average European citizen annually consumes $13.7 \mathrm{~kg}$ beef, $41.0 \mathrm{~kg}$ pork and $22.9 \mathrm{~kg}$ poultry.

Table S.2 list the resulting RED scores associated with the average apparent annual and daily per capita consumption of each product within the EU basket, as well as the RED score per kg (or L) of product.

\section{References}

Notarnicola, B., Tassielli, G., Renzulli, P.A., Castellani, V., Serenella, S., 2017. Environmental impacts of food consumption in Europe. J. Clean. Prod. $140,753-765$ 
Table S.1 Case study - EU food basket of products: ILCD midpoint impacts for the average apparent annual per citizen consumption of the seventeen representative food products in the EU food basket of products, taken from Notarnicola et al. (2017). The results regard the whole life cycle of each basket products from 'cradle to grave' and are reported for an average consumption of one EU-27 citizen in one year (2010). Colour coding for meat products was used to indicate the worst and best performer for each impact category: blue stands for the meat type associated with the lowest impact for the annual per citizen consumption, while pink for the meat type associated with the greatest impact.

\begin{tabular}{|c|c|c|c|c|c|c|c|c|c|c|}
\hline Impact category & Unit & $\begin{array}{c}\text { Mineral } \\
\text { water }\end{array}$ & Beer & Coffee & Apples & Orages & Potatoes & Bread & Olive oil & Sunflower oil \\
\hline Per-capita apparent consumption & $\mathrm{kg} /$ inhabitant & $105(L)$ & $69.8(\mathrm{~L})$ & 3.5 & 16.1 & 17.4 & 70.1 & $39 . .3$ & 5.3 & 5.4 \\
\hline Climate change & $\mathrm{kg} \mathrm{CO}$ 2eq. & $2.9 \mathrm{E}+01$ & $8.0 \mathrm{E}+01$ & $4.0 \mathrm{E}+01$ & $8.3 \mathrm{E}+00$ & $1.2 \mathrm{E}+01$ & $4.6 \mathrm{E}+01$ & $4.4 \mathrm{E}+01$ & $1.3 \mathrm{E}+01$ & $3.9 \mathrm{E}+01$ \\
\hline Ozone depletion & kg CFC-11 $1_{\text {eq }}$. & 3.9E-06 & 1.1E-05 & $5.4 \mathrm{E}-06$ & $1.1 \mathrm{E}-06$ & $1.2 \mathrm{E}-06$ & $6.2 \mathrm{E}-06$ & $6.2 \mathrm{E}-06$ & $1.5 \mathrm{E}-06$ & $1.3 \mathrm{E}-06$ \\
\hline Human toxicity ${ }^{a}$ & $\mathrm{CTU}_{\mathrm{h}}$ & 2.6E-06 & $6.8 \mathrm{E}-05$ & $2.0 \mathrm{E}-06$ & $4.8 \mathrm{E}-07$ & $8.5 \mathrm{E}-07$ & 5.7E-05 & 7.3E-05 & $2.1 \mathrm{E}-06$ & $7.9 \mathrm{E}-05$ \\
\hline Particulate matter & kg $\mathrm{PM}_{2.5}$ eq. & 1.6E-02 & 7.0E-02 & $2.3 \mathrm{E}-02$ & $3.8 \mathrm{E}-03$ & $6.1 \mathrm{E}-03$ & 2.1E-02 & $2.5 \mathrm{E}-02$ & $1.2 \mathrm{E}-02$ & $2.0 \mathrm{E}-02$ \\
\hline Ionising radiation $\mathrm{HH}$ & $\mathrm{kBq} \mathrm{U}^{235} \mathrm{eq}$. & $2.9 \mathrm{E}+00$ & $6.1 \mathrm{E}+00$ & $6.0 \mathrm{E}+00$ & $1.0 \mathrm{E}+00$ & $1.0 \mathrm{E}+00$ & $4.9 \mathrm{E}+00$ & $6.4 \mathrm{E}+00$ & $1.2 \mathrm{E}+00$ & $3.8 \mathrm{E}-01$ \\
\hline Photochemical ozone formation & kg NMVOC & 1.4E-01 & $3.2 \mathrm{E}-01$ & $1.1 \mathrm{E}-01$ & $3.2 \mathrm{E}-02$ & 4.3E-02 & $1.3 \mathrm{E}-01$ & $1.3 \mathrm{E}-01$ & $6.2 \mathrm{E}-02$ & $1.0 \mathrm{E}-01$ \\
\hline Acidification & $\mathrm{mol} \mathrm{H}^{+}$eq. & $1.8 \mathrm{E}-01$ & $8.8 \mathrm{E}-01$ & $5.2 \mathrm{E}-01$ & $7.0 \mathrm{E}-02$ & $1.3 \mathrm{E}-01$ & $4.8 \mathrm{E}-01$ & $6.7 \mathrm{E}-01$ & $1.5 \mathrm{E}-01$ & $7.0 \mathrm{E}-01$ \\
\hline Terrestrial eutrophication & $\mathrm{mol} \mathrm{N}$ eq & 4.6E-01 & $2.6 \mathrm{E}+00$ & $1.4 \mathrm{E}+00$ & $1.9 \mathrm{E}-01$ & 4.7E-01 & $1.6 \mathrm{E}+00$ & $2.4 \mathrm{E}+00$ & 4.6E-01 & $2.8 \mathrm{E}+00$ \\
\hline Freshwater eutrophication & $\mathrm{kg} P_{\text {eq. }}$ & $1.2 \mathrm{E}-03$ & $2.8 \mathrm{E}-02$ & $2.9 \mathrm{E}-03$ & $2.4 \mathrm{E}-04$ & 3.7E-03 & 2.7E-02 & $2.4 \mathrm{E}-02$ & 1.7E-03 & $2.0 \mathrm{E}-02$ \\
\hline Marine eutrophication & $\mathrm{kg} \mathrm{N}$ eq. & 4.8E-02 & 3.3E-01 & $2.4 \mathrm{E}-01$ & $3.0 \mathrm{E}-02$ & $8.1 \mathrm{E}-02$ & $3.6 \mathrm{E}-01$ & 5.7E-01 & $6.6 \mathrm{E}-02$ & $3.9 \mathrm{E}-01$ \\
\hline Freshwater ecotoxicity & CTUe & $1.7 \mathrm{E}+01$ & $4.4 \mathrm{E}+02$ & $4.0 \mathrm{E}+02$ & $4.9 \mathrm{E}+01$ & $9.5 \mathrm{E}+01$ & $8.2 \mathrm{E}+01$ & $7.3 \mathrm{E}+01$ & $2.6 \mathrm{E}+01$ & $2.4 \mathrm{E}+02$ \\
\hline Land use & kg C deficit & $7.0 \mathrm{E}+01$ & $4.0 \mathrm{E}+02$ & $2.8 \mathrm{E}+02$ & $6.5 \mathrm{E}+01$ & $9.9 \mathrm{E}+01$ & $2.2 \mathrm{E}+02$ & $3.4 \mathrm{E}+02$ & $4.8 \mathrm{E}+02$ & $1.4 \mathrm{E}+03$ \\
\hline Water resource depletion & $\mathrm{m}^{3}$ water eq. & $3.3 \mathrm{E}+00$ & $1.3 \mathrm{E}+00$ & $1.4 \mathrm{E}+00$ & $1.8 \mathrm{E}+00$ & $4.1 \mathrm{E}+00$ & $3.1 \mathrm{E}+00$ & $1.1 \mathrm{E}+00$ & $1.4 \mathrm{E}+00$ & $1.7 \mathrm{E}+00$ \\
\hline Resource depletion & $\mathrm{kg} \mathrm{Sb}$ eq. & $8.6 \mathrm{E}-04$ & $3.5 \mathrm{E}-03$ & $1.0 \mathrm{E}-03$ & $1.6 \mathrm{E}-04$ & $3.8 \mathrm{E}-04$ & $2.0 \mathrm{E}-03$ & $3.8 \mathrm{E}-04$ & 7.0E-04 & $8.2 \mathrm{E}-04$ \\
\hline Impact category & Unit & Sugar & Milk & Cheese & Butter & $\begin{array}{c}\text { Meat - } \\
\text { beef }\end{array}$ & $\begin{array}{c}\text { Meat - } \\
\text { pork }\end{array}$ & $\begin{array}{l}\text { Meat - } \\
\text { poultry }\end{array}$ & $\begin{array}{c}\text { Pre- } \\
\text { prepared } \\
\text { meal }\end{array}$ & Total \\
\hline Per-capita apparent consumption & $\mathrm{kg} /$ inhabitant & 29.8 & 80.1 & 15.0 & 3.6 & 13.7 & 41.0 & 22.9 & 2.9 & 540.9 \\
\hline Climate change & $\mathrm{kg} \mathrm{CO}_{\text {2eq. }}$ & $3.1 \mathrm{E}+01$ & $1.1 \mathrm{E}+02$ & $1.9 \mathrm{E}+02$ & $8.7 \mathrm{E}+01$ & $3.1 \mathrm{E}+02$ & $2.7 \mathrm{E}+02$ & $1.4 \mathrm{E}+02$ & $1.8 \mathrm{E}+01$ & $1.4 \mathrm{E}+03$ \\
\hline Ozone depletion & kg CFC-11 1 eq. & 1.4E-06 & 4.6E-06 & $6.9 \mathrm{E}-06$ & $9.9 \mathrm{E}-07$ & 8.1E-07 & $3.9 \mathrm{E}-06$ & $2.1 \mathrm{E}-06$ & $1.6 \mathrm{E}-06$ & $6.0 \mathrm{E}-05$ \\
\hline Human toxicity ${ }^{a}$ & $\mathrm{CTU}_{\mathrm{h}}$ & 7.5E-05 & $2.0 \mathrm{E}-04$ & $3.5 \mathrm{E}-04$ & $2.0 \mathrm{E}-04$ & 3.4E-04 & 4.4E-04 & $1.6 \mathrm{E}-04$ & $1.3 \mathrm{E}-05$ & 2.1E-03 \\
\hline Particulate matter & kg $\mathrm{PM}_{2.5}$ eq. & 2.7E-02 & $6.0 \mathrm{E}-02$ & $9.5 \mathrm{E}-02$ & 4.7E-02 & $1.8 \mathrm{E}-01$ & $1.6 \mathrm{E}-01$ & 7.4E-02 & $9.6 \mathrm{E}-03$ & $8.5 E-01$ \\
\hline
\end{tabular}




\begin{tabular}{|c|c|c|c|c|c|c|c|c|c|c|}
\hline lonising radiation $\mathrm{HH}$ & $\mathrm{kBq} \mathrm{U}^{235} \mathrm{eq}$. & $5.4 \mathrm{E}-01$ & $3.8 \mathrm{E}+00$ & $5.8 \mathrm{E}+00$ & $9.2 \mathrm{E}-01$ & $6.0 \mathrm{E}-01$ & $3.7 \mathrm{E}+00$ & $2.0 \mathrm{E}+00$ & $1.7 \mathrm{E}+00$ & $4.9 \mathrm{E}+01$ \\
\hline Photochemical ozone formation & kg NMVOC & $8.2 \mathrm{E}-02$ & $2.2 \mathrm{E}-01$ & $2.8 \mathrm{E}-01$ & $1.0 \mathrm{E}-01$ & 4.1E-01 & 4.2E-01 & 2.0E-01 & $4.0 \mathrm{E}-02$ & $2.8 \mathrm{E}+00$ \\
\hline Acidification & $\mathrm{mol} \mathrm{H}^{+}$eq. & $1.0 \mathrm{E}+00$ & $2.2 \mathrm{E}+00$ & $3.7 \mathrm{E}+00$ & $2.0 \mathrm{E}+00$ & $7.5 \mathrm{E}+00$ & $6.7 \mathrm{E}+00$ & $2.7 \mathrm{E}+00$ & $2.1 \mathrm{E}-01$ & $3.0 \mathrm{E}+01$ \\
\hline Terrestrial eutrophication & $\mathrm{mol} \mathrm{N}$ eq & $4.4 \mathrm{E}+00$ & $9.2 \mathrm{E}+00$ & $1.6 \mathrm{E}+01$ & $8.8 \mathrm{E}+00$ & $3.3 E+01$ & $3.0 \mathrm{E}+01$ & $1.2 \mathrm{E}+01$ & 7.0E-01 & $1.3 E+02$ \\
\hline Freshwater eutrophication & kg $P_{\text {eq. }}$. & $6.8 \mathrm{E}-03$ & 7.1E-02 & $7.2 \mathrm{E}-02$ & $1.2 \mathrm{E}-02$ & $5.6 \mathrm{E}-02$ & $8.9 \mathrm{E}-02$ & $1.8 \mathrm{E}-02$ & $1.9 \mathrm{E}-03$ & 4.4E-01 \\
\hline Marine eutrophication & $\mathrm{kg} \mathrm{N}$ eq. & 4.9E-01 & $9.5 \mathrm{E}-01$ & $1.6 \mathrm{E}+00$ & $6.3 \mathrm{E}-01$ & $2.4 \mathrm{E}+00$ & $2.6 \mathrm{E}+00$ & $1.1 \mathrm{E}+00$ & $8.0 \mathrm{E}-02$ & $1.2 \mathrm{E}+01$ \\
\hline Freshwater ecotoxicity & CTUe & $7.4 \mathrm{E}+01$ & $2.9 \mathrm{E}+02$ & $4.9 E+02$ & 2.7E+02 & $5.5 \mathrm{E}+02$ & $8.6 \mathrm{E}+02$ & $3.8 \mathrm{E}+02$ & $5.0 \mathrm{E}+01$ & $4.4 E+03$ \\
\hline Land use & kg C deficit & $3.0 \mathrm{E}+02$ & $8.2 \mathrm{E}+02$ & $1.4 \mathrm{E}+03$ & $7.7 \mathrm{E}+02$ & $2.9 \mathrm{E}+03$ & $3.2 \mathrm{E}+03$ & $1.7 \mathrm{E}+03$ & $1.2 \mathrm{E}+02$ & $1.5 E+04$ \\
\hline Water resource depletion & $\mathrm{m}^{3}$ water eq. & $2.5 \mathrm{E}+00$ & $3.3 E+00$ & $8.7 E+00$ & $6.5 \mathrm{E}-01$ & $5.5 \mathrm{E}+00$ & 1.7E+00 & $1.1 \mathrm{E}+00$ & $1.0 \mathrm{E}+00$ & $4.4 E+01$ \\
\hline Resource depletion & $\mathrm{kg} \mathrm{Sb}$ eq. & $3.9 \mathrm{E}-04$ & $1.2 \mathrm{E}-03$ & 9.7E-04 & $8.5 \mathrm{E}-04$ & 8.1E-04 & $1.1 \mathrm{E}-03$ & $6.1 \mathrm{E}-04$ & $1.8 \mathrm{E}-04$ & $1.6 \mathrm{E}-02$ \\
\hline
\end{tabular}

${ }^{a}$ Human toxicity impacts were referred to as one single (cumulative) impact category in the table of Notarnicola et al. (2017), while within ILCD this refers to two separate human toxicity impact categories (cancer and non-cancer effects). 
1 Table S.2 Case study - EU food basket of products: Resulting RED scores for the average apparent annual and daily per citizen consumption of the seventeen representative

2 food products in the EU food basket of products, as well as the RED score per kg (or liter) of product.

\begin{tabular}{|c|c|c|c|c|}
\hline Food product & $\begin{array}{c}\text { Annual RED score for apparent } \\
\text { consumption (RED Pt) }\end{array}$ & $\begin{array}{l}\text { Daily RED score for apparent } \\
\text { consumption (RED Pt) }\end{array}$ & $\begin{array}{l}\text { Apparent annual per capita consumption } \\
\text { (kg or L /inhabitant) }\end{array}$ & $\begin{array}{l}\text { RED impact per kg or L of product } \\
\text { (RED Pt) }\end{array}$ \\
\hline Apples & $2.34 \mathrm{e}-2$ & $6.40 e-5$ & 96.6 & $1.45 e-3$ \\
\hline Beer & $2.24 \mathrm{e}-1$ & $6.14 \mathrm{e}-4$ & 418.8 & $3.21 \mathrm{e}-3$ \\
\hline Bread & $2.16 \mathrm{e}-1$ & $5.93 e-4$ & 235.8 & $5.51 e-3$ \\
\hline Butter & $1.84 \mathrm{e}-1$ & $5.05 e-4$ & 21.6 & $5.12 \mathrm{e}-2$ \\
\hline Cheese & $7.07 e-1$ & $1.94 \mathrm{e}-3$ & 90 & $4.71 \mathrm{e}-2$ \\
\hline Coffee & $7.39 e-2$ & $2.02 \mathrm{e}-4$ & 21 & $2.11 \mathrm{e}-2$ \\
\hline Meat - beef & $7.68 \mathrm{e}-1$ & $2.10 \mathrm{e}-3$ & 82.2 & $5.60 \mathrm{e}-2$ \\
\hline Meat - pork & $9.12 \mathrm{e}-1$ & $2.50 \mathrm{e}-3$ & 246 & $2.23 \mathrm{e}-2$ \\
\hline Meat-poultry & $3.08 \mathrm{e}-1$ & $8.45 e-4$ & 137.4 & $1.35 \mathrm{e}-2$ \\
\hline Milk & $5.42 \mathrm{e}-1$ & $1.49 e-3$ & 480.6 & $6.77 e-3$ \\
\hline Mineral water & $5.03 e-2$ & $1.38 \mathrm{e}-4$ & 630 & $4.79 e-4$ \\
\hline Olive oil & $4.01 \mathrm{e}-2$ & $1.10 \mathrm{e}-4$ & 31.8 & $7.57 e-3$ \\
\hline Oranges & $6.67 e-2$ & $1.83 e-4$ & 104.4 & $3.83 e-3$ \\
\hline Potatoes & $2.21 \mathrm{e}-1$ & $6.06 \mathrm{e}-4$ & 420.6 & $3.15 e-3$ \\
\hline Pre-prepared meal & $3.57 e-2$ & $9.77 e-5$ & 17.4 & $1.23 e-2$ \\
\hline Sugar & $1.28 \mathrm{e}-1$ & $3.51 \mathrm{e}-4$ & 178.8 & $4.30 e-3$ \\
\hline Sunflower oil & $1.95 \mathrm{e}-1$ & $5.35 e-4$ & 32.4 & $3.62 \mathrm{e}-2$ \\
\hline TOTAL & 4.71 & $1.29 \mathrm{e}-2$ & 540.9 & \\
\hline
\end{tabular}

